\title{
PENGARUH SUDUT LOUVERED STRIPS TERHADAP LAJU PERPINDAHAN PANAS PADA COUNTER FLOW HEAT EXCHANGER
}

\author{
Oleh \\ Nyoman Arya Wigraha \\ Jurusan Teknik Elektronika, FTK, UNDIKSHA
}

\begin{abstract}
ABSTRAK
Pengaruh turbulator Louvered strips terhadap laju perpindahan kalor dan faktor gesekan aliran turbulen pada double tube heat exchanger dapat memecah (partitioning) dan mengganggu (blockage) pola streamline dari fluida yang mengalir ke saluran pipa dalam (inner tube) sehingga mengakumulasi aliran turbulensi dan meningkatkan laju perpindahan kalor dalam pipa. Louvered strips memiliki variasi sudut serang $\left(\theta=15^{\circ}, 25^{\circ}, 30^{\circ}\right)$ yang terpasang ditengah-tengah pipa bagian dalam dan searah aliran fluida masuk. Laju aliran fluida (air) panas di bagian pipa dalam diteliti dengan interval 400 lt/jam sampai 900 lt/jam dan laju aliran air dingin di bagian pipa luar konstan $900 \mathrm{lt} / \mathrm{jam}$. Data hasil pengujian dari masing - masing sudut serang turbulator ini dibandingkan data tanpa turbulator (plain tube), secara keseluruhan terjadi peningkatan laju perpindahan kalor sebesar $26 \%$ sampai $58 \%$ dari pada tanpa turbulator serta menghasilkan faktor gesekan dari $25 \%$ sampai 40 $\%$. Dengan performance ratio rata -rata tertinggi pada turbulator dengan sudut $30^{\circ}$ sebesar 0,948 .
\end{abstract}

Kata kunci: Louvered strips, Heat Exchanger, Counter flow, turbulensi, faktor gesekan, turbulator, efektifitas

\section{ABSTRACT}

Effect of turbulator louvered strips on the rate of heat transfer and friction factor of turbulent flow in a double tube heat exchanger can be split (partitioning) and interrupt (blockage) streamline pattern of the fluid flowing into the pipeline (inner tube) that accumulates the flow turbulence and increase the rate of displacement heat in the pipeline. Louvered strips have a variation of angle of attack $\left(\theta=15^{\circ}, 25^{\circ}, 30^{\circ}\right)$ which is attached in the middle of the inner pipe and the direction of fluid flow inside. The flow rate of fluid (water) heat in the pipe in the interval studied $400 \mathrm{lt} /$ hour to 900 liters / hour and the cold water flow rate in the outer pipe of constant $900 \mathrm{lt} /$ hour. Data from each test result - each turbulator angle of attack is compared to data without turbulator (plain tube), the overall heat transfer rate increased by $26 \%$ to $58 \%$ of the no turbulator as well as generate friction factor from $25 \%$ to $40 \%$. Performance ratio with the highest average in the turbulator with 30 o angle of 0.948 .

Key words: louvered strips, Heat Exchanger, Counter flow, turbulence, friction factor, turbulator, effectiveness

Pengaruh Sudut Louvered Strips Terhadap Laju ............. ( Nyoman Arya Wigraha) 


\section{PENDAHULUAN}

Peningkatan efisiensi dari perpindahan energi perlu adanya perubahan parameter - parameter, antara lain perubahan parameter aliran fluida (turbulensi), perubahan area penerimaan energi dan pengkondisian temperatur fluida kerja. Faktor perubahan parameter tersebut sangat penting dalam kontrol suatu proses Engineering baik di Power Plant Industry, Production Processing Utility dll yang akan menentukan kualitas produk yang dihasilkan (Lunsford,1998). Dalam dunia industri pemanfaatan kembali perpindahan energi atau panas sangat diperlukan, dimana perpindahan kalor dapat berlangsung melalui 3 cara, antara lain perpindahan kalor secara molekuler (konduksi), secara aliran (konveksi), secara gelombang elektromagnet (radiasi). Aplikasi perpindahan kalor tersebut banyak ditemui secara rinci dengan penggunaan Heat Exchanger baik berupa kondensor, recuperator, boiler dll. Heat exchanger adalah peralatan yang digunakan untuk memindahkan energi termal (Entalpi) antara dua atau lebih fluida, antara permukaan padat (solid) dan cair/gas, atau antara partikel padat dan partikel cair/gas, pada perbedaan temperatur dan area kontak termal fluida/konveksi paksa, sedangkan roses perpindahan kalor HE ada dua yaitu tipe direct dan indirect (Shah, 2003).

Pengembangan perpindahan kalor dari HE terbagi menjadi beberapa cara yaitu secara cara passive dan active (Lunsford,1998) : Pengembangan HE passive techniq yaitu merekayasa aliran fluida kerja melalui penambahan area permukaan perpindahan panas (turbulator) pada pipa - pipa HE seperti pengasaran permukaan dinding dalam/luar pipa, alat pemusar aliran/swirler/penghalang, external atau internal fin, dll. Sedangkan secara active techniq yaitu dengan memberikan penambahan energi ke fluida kerja seperti pemberian getaran secara mekanik ke area fluida kerja agar dapat memecah lapisan batas kalor. Pengembangan perpindahan kalor dari Heat exchanger dimaksudkan untuk mengatasi permasalahan permasalahan seperti laju perpindahan kalor, area pemukaan perpindahan kalor, faktor gesekan, pola aliran fluida kerja, daya pompa, jenis Heat Exchanger yang digunakan, serta jenis material HE(Bergles, 1998). Dalam penelitian ini akan mengembangkan teknik passive yaitu dengan memodifikasi dan menggabungkan tipe turbulator insert HE Louverd strips Insert (Smith Eiamsa-ard;2007) dan Twisted 
tape Insert atau disebut "Louvered Strips Inserts" yang memiliki variasi sudut serang sirip $\theta=15^{\circ}, 25^{\circ}$ dan $30^{\circ}$. Pemasangan turbulator dapat memecah (partitioning) dan mengganggu (blockage) pola streamline dari fluida yang mengalir ke saluran pipa dalam (inner tube). Dengan kata lain akan mengalirkan aliran fluida sesuai dengan arah vektor pergerakkan fluida sesuai dengan bentuk dan model turbulator. Akibatnya lintasan dan luasan bebas alir fluida dalam pipa berkurang sehingga akan meningkatkan kecepatan alir fluida. Kecepatan pada fluida ini akan meningkatkan kontak termal antara permukaan pipa dalam dengan fluida yang mengalir. Hal ini merupakan adanya rotasi ( curl) fluida yang bersinggungan dengan penghalang turbulator dimana ada perbedaan tekanan lokal sehingga mengakibatkan olakan - olakan aliran berpusar fluida (swirl) diantara ruang antar sirip (fin) turbulator (Saunders,1986). Fluida yang berpusar ini akan memperbesar gradien temperatur artinya ada pelepasan kalor yang besar ke sekitarnya akibat meningkatkan pergerakan partikel fluida (turbulensi) untuk mentransferkan energinya keluar atau memiliki koefisien mampu pindah kalor yang tinggi (high heat transfer coefficient). Pemasangan turbulator juga menerapkan konveksi paksa, hal ini berkaitan dengan besarnya energi diterima ke dalam fluida maupun perpindahan kalor antar pipa dan fluida.

\section{METODE PENELITIAN}

\subsection{Peralatan Penelitian}

Dalam penelitian ini menggunakan double tube heat exchanger, dengan pipa bagian luar dari stainles steel berdiameter dalam 76,2 mm dengan dan pipa bagian dalam dari tembaga bediameter 25,4 mm dengan panjang 1,1 meter. Fluida yang digunakan adalah air baik pada pipa bagian luar (shell) dan pipa bagian dalam (tube) sedangkan arah aliran dalam heat exchanger ini yaitu counter flow. Untuk kerugian pipa dan kerugian panas ke lingkungan diabaikan karena sistem dianggap steady. Pengukuran pressure drop pada pipa bagian dalam menggunakan manometer. Air dingin mengalir konstan pada pipa luar (shell) 900 lt/jam dan temperaturnya dijaga konstan $27^{\circ} \mathrm{C}$. Sedangkan pada air panas mengalir pada pipa dalam (tube) bervariasi dari 400 lt/jam sampai 900 lt/jam dengan kenaikan interval 100 lt/jam dan temperatur 
reservoirnya konstan $65^{\circ} \mathrm{C}$ dengan toleransi temperatur $\pm 0,1^{\circ} \mathrm{C}$. Untuk menjaga temperatur air panas maka digunakan daya heater $2400 \mathrm{KW}$ serta menggunakan automaticthermocontroler sedangkan untuk menjaga temperatur reservoir dingin maka digunakan sirkulasi dengan air PDAM. Louvered strips insert ini berjumlah 22 buah dan terbuat dari stainless steel dengan variasi sudut serang $\theta=15^{\circ}, 25^{\circ}$, $30^{\circ}$. Ukuran dan bentuk turbulator ini seperti pada gambar 2.

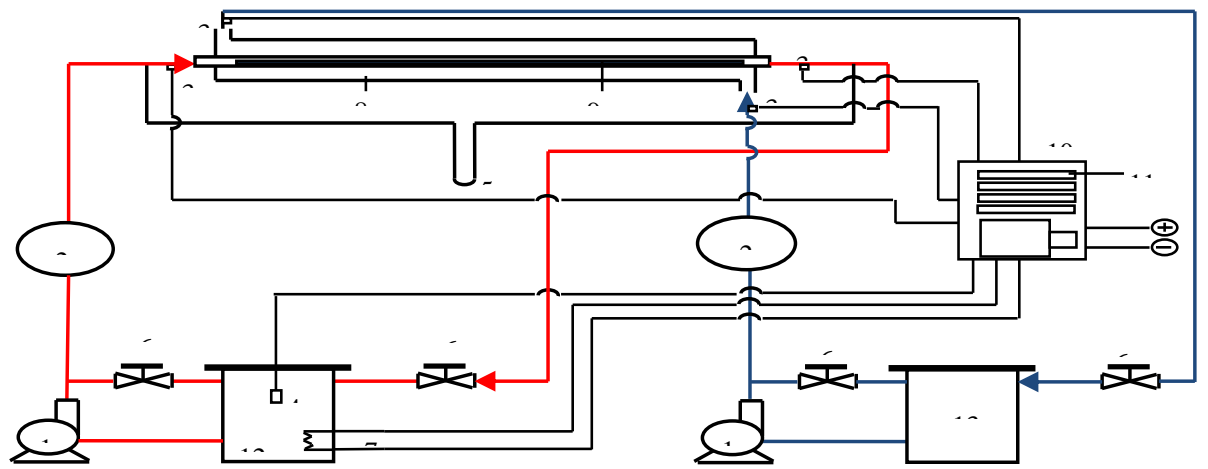

Gambar 1. Skema peralatan penelitian:1 pompa air 1/4 PK, 2 Debit meter, 3 LM 35, 4 Thermocouple tipe K, 5 Manometer, 6 Ball Valve, 7 Heater, 8 Double tube HE, 9 Louvered strip twisted insert, 10 control panel, 11 Display digital, 12 \& 13 Reservoir air panas dan dingin.

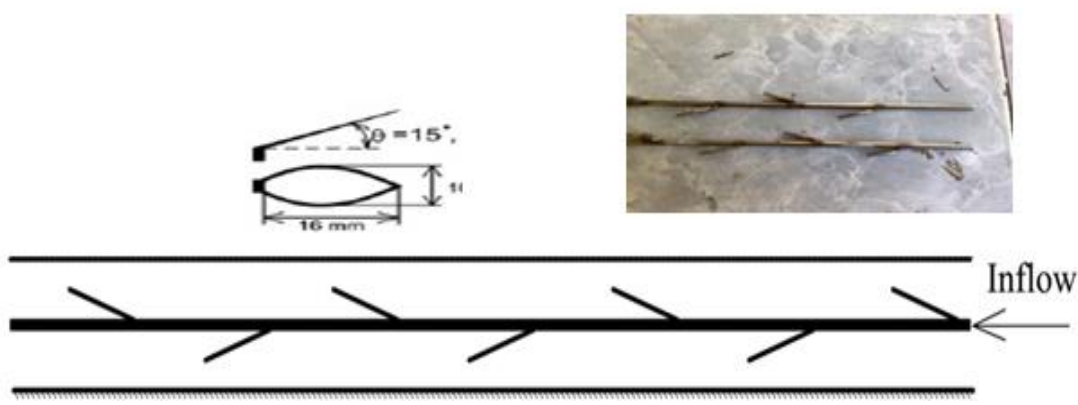

Gambar 2. Ukuran dan bentuk turbulator

\subsection{Prosedur Penelitian}

Dalam penelitian ini air dimasukkan ke reservoir air panas dan air dingin. Kemudian dilakukan kalibrasi pada debit meter untuk air dingin sebesar 900 lt/jam dan debit meter air panas dari 400 lt/jam - 900 lt/jam dimana kalibrasi ini dilakukan tiap kenaikan interval 100 lt/jam. Air pada reservoir panas dipanaskan dengan heater 
sampai suhunya $65^{\circ} \mathrm{C}$, setelah itu pompa air panas dinyalakan untuk mengalirkan air kedalam pipa dalam (tube) sampai kondisi steady pada temperatur Thin $\left(65^{\circ} \mathrm{C}\right)$ dan Thout yang terbaca pada display digital serta steady perbedaan ketinggian yang terukur pada manometer. Dan selanjutnya reservoir air dingin yang berkondisi steady pada suhu $27^{\circ} \mathrm{C}$ (Tcin) dialirkan ke dalam pipa luar (shell) melalui pompa air dingin. Setelah itu dilakukan pencatatan dan pengambilan data 5 kali dengan pengulangan 3 kali dari temperatur Thin, Thout, Tcin,Tcout dan $\Delta \mathrm{z}$ (perbedaan ketinggian $\mathrm{cmH}_{2} \mathrm{O}$ ). Prosedur penelitian ini dilakukan pada plain tube dan Heat exchnager dengan turbulator Louvered strips insert.

Perubahan temperatur Thin, Thout, Tcin,Tcout berpengaruh terhadap propertis fluida antara lain $\operatorname{Pr}, \rho, c p, v, k, \mu$ yang didapatkan di tabel melalui berdasarkan temperatur rata - rata fluida dingin dan fluida panas (temperatur bulk), $T_{\text {bulk hot }}=\left(T_{\text {hin }}+T_{\text {hout }}\right) / 2$ dan $T_{\text {bulk cold }}=\left(T_{\text {cin }}+T_{\text {cout }}\right) / 2$

Maka laju perpindahan kalor double tube heat exchanger ;

Karena aliran fluida pada double tube heat exchanger ini crossflow maka ;

$$
\Delta T_{L M T D}=\frac{\Delta T_{1}-\Delta T_{2}}{\ln \left(\Delta T_{1} / \Delta T_{2}\right)} \text { dengan } \quad \begin{aligned}
\Delta T_{1}=T_{h, \text { in }}-T_{c, \text { out }} \\
\Delta T_{2}=T_{h, \text { out }}-T_{c, \text { in }}
\end{aligned}
$$

Luasan permukaan total perpindahan kalor As ;

As = Luasan permukaan pipa dalam + Luas total turbulator

Dimana luas total sirip ini dipengaruhi sudut sinus dari louvered strip twisted insert $\theta=15^{\circ}, 25^{\circ}$ dan $30^{\circ}$. Koefisien perpindahan kalor $U$;

$$
U=\frac{1}{\frac{1}{h_{i} A_{i}}+\frac{\ln \left(D_{o} / D_{i}\right)}{2 \pi k L}+\frac{1}{h_{o} A_{o}}}
$$

Dimana $A_{i}$ dan $A_{o}$ adalah luasan total permukaan perpindahan kalor pipa dalam bagian dalam

$$
A_{o}=\pi D_{o} L \text { dan } A_{i}=\pi D_{i} L
$$

dengan koefisien konveksi ;

$$
h_{\text {in,out }}=\frac{k_{\text {in,out }}}{D_{h}} N u_{\text {in }, \text { out }}
$$


Untuk perhitungan angka Nusselt dari pipa luar dan pipa dalam pada double tube heat exchanger ini dengan menggunakan persamaan Dittus-Boilter :

$$
\begin{gathered}
N u_{o}=\frac{h_{o} \cdot D_{h}}{k}=0.023 \operatorname{Re}_{o}^{0.8} \operatorname{Pr}_{o}^{0.33} \\
N u_{i}=\frac{h_{i} \cdot D_{h}}{k}=0.023 \operatorname{Re}_{i}^{0.8} \operatorname{Pr}_{i}^{0.4}
\end{gathered}
$$

Dimana $D_{h}=D_{o}-D_{i}$ adalah diameter hidrolik yang dipengaruhi luasan aliran fluida (perimeter basah) di dalam pipa - pipa Heat exchanger. Dan angka Reynold berdasarkan ;

$$
\begin{gathered}
R e_{\text {in,out }}=\frac{u \cdot D}{v}=\frac{\rho_{\text {in,out }} \cdot u_{\text {in,out }} \cdot D_{\text {im }, \text { out }}}{\mu_{\text {in,out }}} \\
Q=U A_{s} \Delta T_{L M T D}
\end{gathered}
$$

Sedangkan capacity ratio (c) dan Number of Transfer Unit :

Hubungan antara NTU dan capacity ratio (c) terhadap efektivitas (ع) pada counter flow heat exchanger, sebagai berikut :

$$
f=\frac{\Delta P}{\left(\frac{L}{D}\right)\left(\rho \frac{u^{2}}{2}\right)}
$$

Sedangkan faktor gesekan didalam pipa untuk aliran turbulen dipengaruhi besarnya penurunan tekanan $(\Delta \mathrm{P})$ sebagai akibat adanya hambatan dari pemasangan turbulator louvered strip kedalam pipa heat exchanger. Artinya dengan semakin besar penurunan tekanan maka faktor gesekan akan bertambah besar, sehingga kerja pompa akan meningkat ;

\section{HASIL DAN PEMBAHASAN}

Dari gambar 3 dapat dilihat dengan adanya pemasangan berbagai variasi sudut louvered strips, maka akan semakin besar sudut louvered strips maka akan semakin besar faktor gesekan. Faktor gesekan akan semakin menurun dengan kenaikan debit dikarenakan hambatan pada fluida panas semakin besar dengan kecepatan fluida semakin besar, meskipun penurunan tekanan semakin besar 


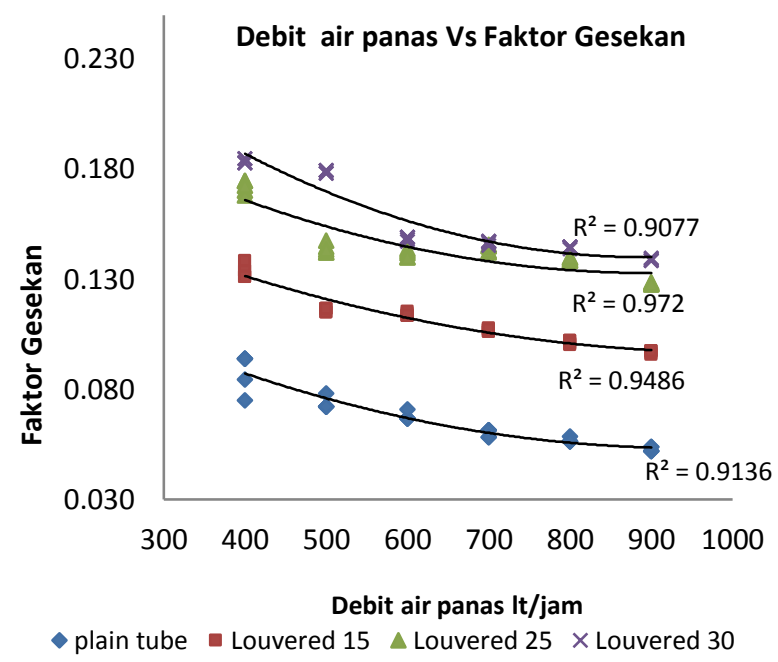

Gambar 3 Grafik pengaruh berbagai variasi sudut louvered strips terhadap faktor gesekan pada berbagai variasi debit air panas

$$
\begin{gathered}
c=\frac{C_{\min }}{C_{\max }} \text { dan } \quad N T U=\frac{U A_{s}}{C_{\min }}=\frac{U A_{s}}{\left(\dot{m} C_{p}\right)_{\min }} \\
\varepsilon=\frac{1-\exp [-N T U(1-c)]}{1-c \exp [-N T U(1-c)]}
\end{gathered}
$$

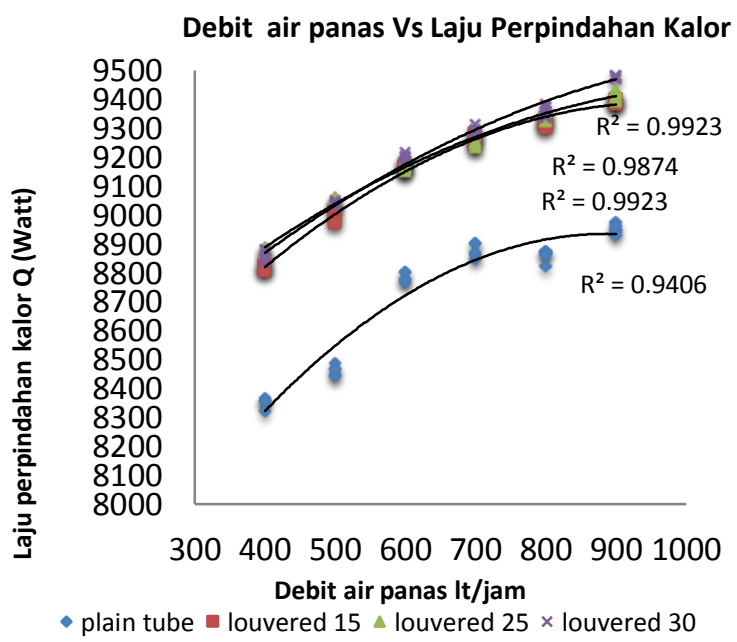

Gambar 4 Grafik pengaruh berbagai variasi sudut louvered strips terhadap laju perpindahan kalor yang ditimbulkan pada berbagai variasi debit

Pada gambar 4 menunjukkan bahwa dengan adanya pemasangan penghalang dengan variasi sudut louvered strips menyebabkan terjadinya peningkatan laju 
perpindahan kalor dibandingkan dengan tanpa penghalang, sebanding dengan peningkatan debit air panas, disebabkan semakin besar sudut dari louvered strips akan mempersempit penampang sehingga meningkatkan kecepatan rata-rata dari fluida dan akan semakin tinggi laju perpindahan kalornya.

Pada gambar 5 ditunjukkan grafik perbandingan angka Reynold pada plain tube dengan angka Nusselt pada berbagai variasi sudut louvered strips. Dapat dilihat adanya kenaikan angka Nusselt dari penghalang dengan berbagai variasi sudut louvered strips dibandingkan dengan tanpa penghalang, yang mana semakin besar angka Nusselt, maka perpindahan kalor konveksi akan semakin efektif, dimana angka Nusselt menunjukkan besar perpindahan kalor konveksi terhadap besar perpindahan kalor konduksi pada lapisan fluida yang sama.

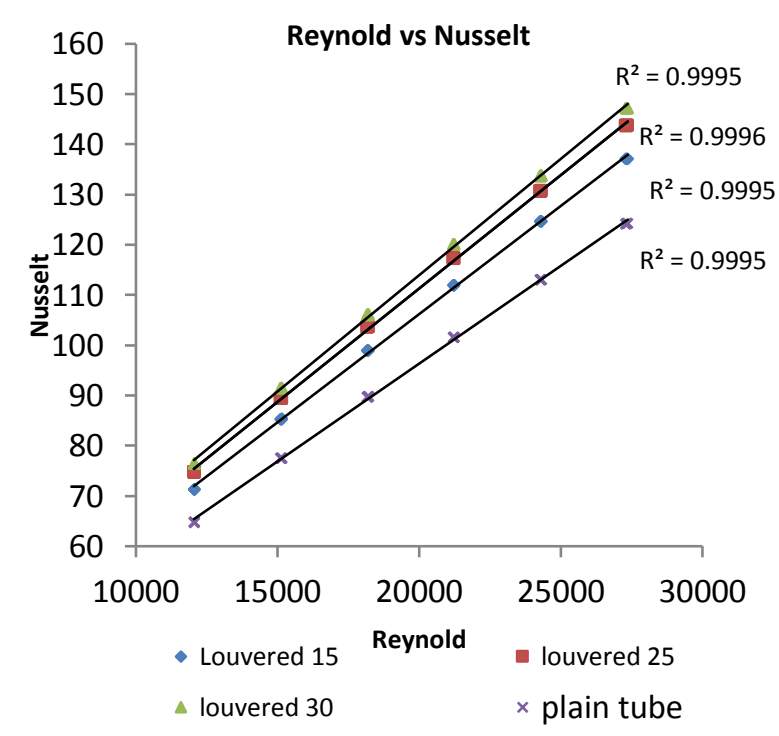

Gambar 5 Grafik perbandingan angka Nusselt dari berbagai variasi sudut louvered strips dengan dengan angka Reynold 


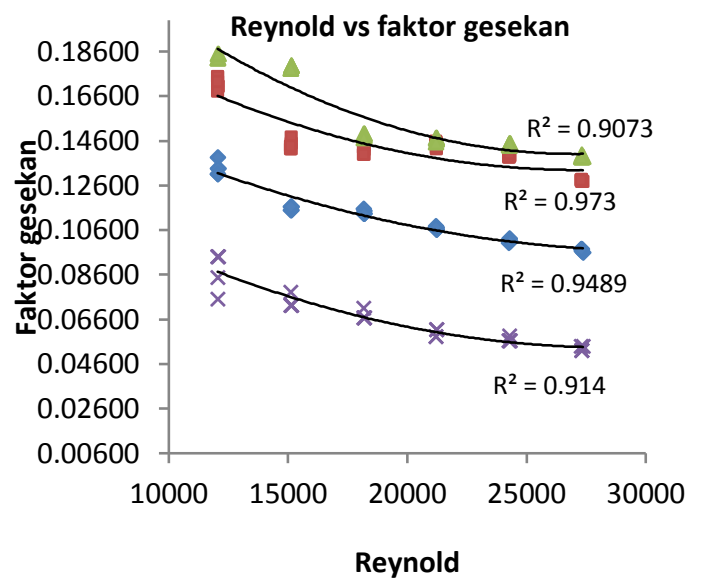

$\bullet$ louvered $15-$ louvered $25 \Delta$ louvered $30 \times$ plain tube

Gambar 6 Grafik perbandingan angka Reynold dengan faktor gesekan berbagai variasi sudut louvered strips

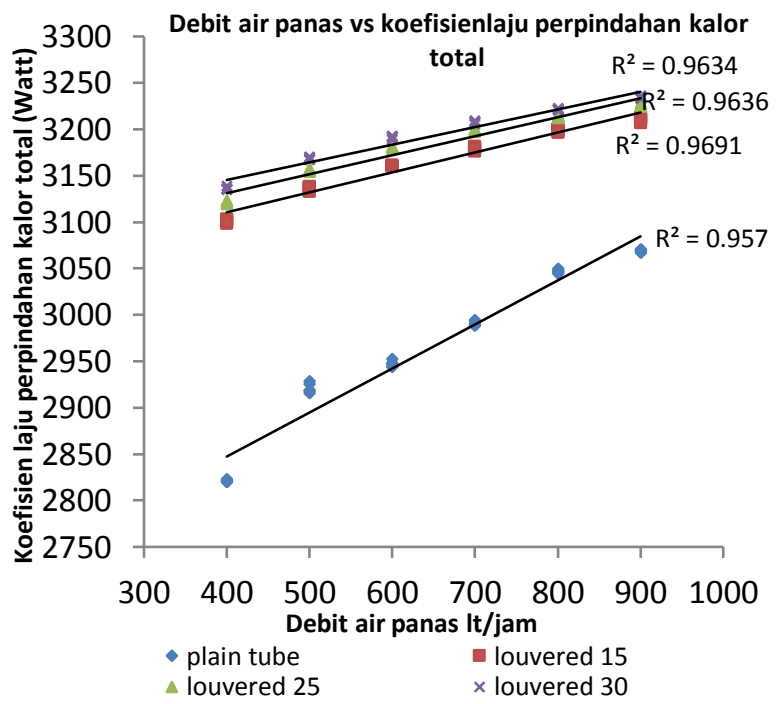

Gambar 7 Grafik perbandingan debit air panas dengan koefisien laju perpindahan kalor total pada berbagai sudut louvered strips

Pada gambar 6 dapat dilihat dengan kenaikan angka Reynold diikuti dengan penurunan faktor gesekan, penurunan faktor gesekan akan meningkatkan gaya inersia yang menimbulkan fluktuasi fluida yang cepat dan acak yang akan meningkatkan turbulensi yang akan menaikkan bilangan Reynold.

Pada gambar 7 dapat dilihat pada debit air panas yang sama didapatkan peningkatan terhadap koefisien perpindahan kalor menyeluruh pada masing-masing pengujian 
dengan variasi sudut louvered strips, peningkatan terhadap koefisien perpindahan kalor menyeluruh dapat menunjukkan bahwa proses perpindahan kalor melalui mekanisme perpindahan kalor konveksi pada pipa dalam akan semakin efektif seiring dengan adanya peningkatan sudut louvered strips sehingga hambatan thermal konveksi pada aliran fluida panas juga semakin kecil.

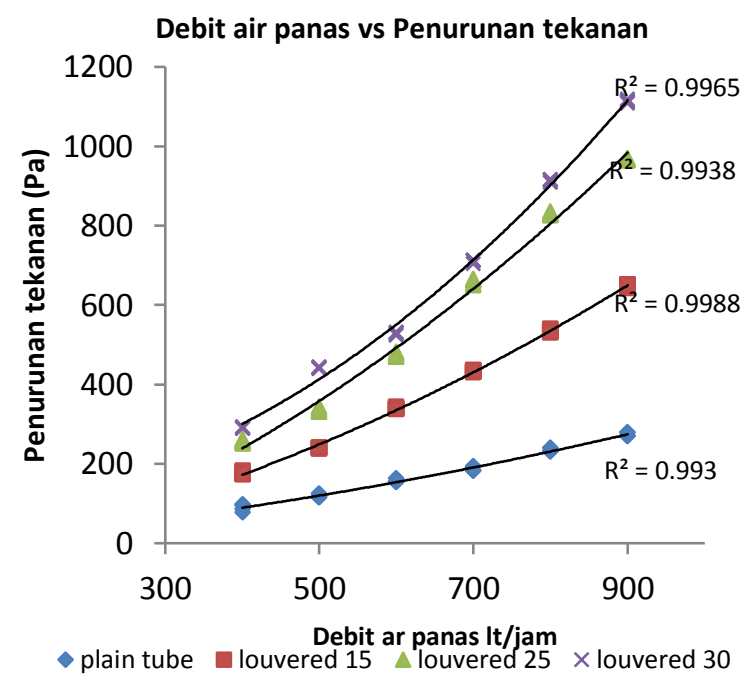

Gambar 8 Hubungan antara variasi debit air panas dengan terhadap penurunan tekanan pada tiap-tiap variasi sudut louvered strips

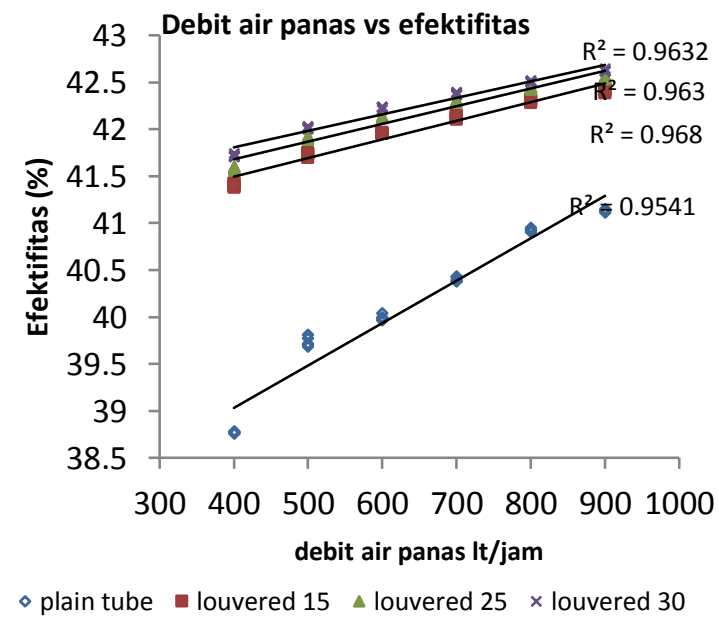

Gambar 9 Grafik pengaruh debit air panas terhadap efektifitas pada tiap-tiap variasi sudut louvered strips 
Gambar 8 dapat dilihat semakin meningkatnya sudut louvered strips akan meningkatkan faktor kerugian komponen pada aliran air panas. Pemasangan louvered strip menyebabkan luas penampang aliran air panas menjadi lebih kecil, akibatnya aliran air akan mempunyai kecepatan yang lebih untuk mempertahankan debit aliran air panas pada debit yang sama, sehingga gesekan dengan dinding pipa dalam maupun dengan louvered strips juga akan semakin meningkat, sehingga penurunan tekanan juga akan semakin meningkat

Gambar 9 dapat dilihat dengan semakin meningkatnya debit aliran pada masing-masing pengujian dengan maupun tanpa pemasangan louvered, efektifitas cenderung meningkat, hal ini disebabkan dengan adanya peningkatan debit maka gerakan fluida akan semakin cepat menggantikan fluida panas yang lebih rendah suhunya di sekitar permukaan dinding pipa dalam dengan partikel fluida panas yang lain, temperatur keluar fluida menjadi lebih panas dibandingkan dengan aliran fluida pada debit yang lebih rendah.

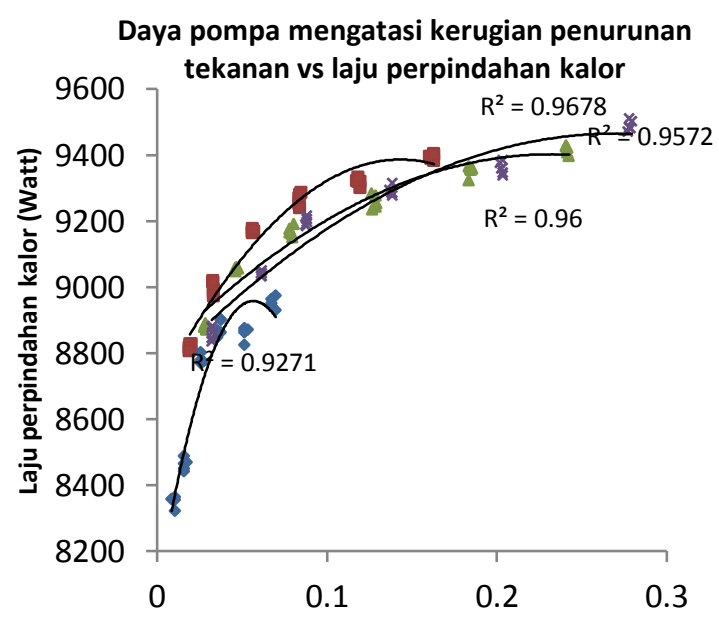

Daya pompa (Watt)

Gambar 10. Grafik perbandingan daya pompa untuk mengatasi kerugian penurunan tekanan dengan laju perpindahan kalor pada berbagai variasi sudut louvered strips

Gambar 10 menunjukkan grafik perbandingan daya pompa yang digunakan untuk mengatasi kerugian penurunan tekanan dengan laju perpindahan kalor pada 
berbagai variasi sudut louvered strips pada daya pompa yang sama, dengan semakin naiknya laju perpindahan kalor maka akan semakin meningkat daya pompa yang dibutuhkan untuk mengatasi kerugian penurunan tekanan.

\section{PENUTUP}

Dari penelitian pengaruh louvered strips terhadap laju perpindahan panas dan faktor gesekan dapat disimpulkan

1. Semakin besar sudut louvered strips dengan bertambahnya debit air panas pada masing-masing pengujian dengan variasi debit air panas yang sama akan meningkatkan laju perpindahan kalor, menurunkan tekanan, dan meningkatkan efektifitas.

2. Faktor gesekan akan semakin menurun dengan meningkatnya debit air panas pada berbagai variasi sudut louvered strips, dikarenakan hambatan pada fluida panas semakin besar dengan kecepatan fluida semakin besar, meskipun penurunan tekanan semakin besar

\section{DAFTAR PUSTAKA}

Bejan, Adrian \& Kraus, Allan D. 2003. Heat transfer hanbook. Hoboken : New Jersey. John Wiley and Sons, Inc.

Bergles, A.E. 1998. The imperative to enhance heat transfer, in : Energy conservation through heat transfer enhancement of heat exchangers. NATO Advanced Study Institute. Izmir - Turkey.

Byron Black of the Brown Fintube Company. Heat transfer innovators. URL : http://www.kochheattransfer.com/cp/userfile_Byron_black_of_the_brown_fin tube_company.pdf. 16 februari 2010.

Cengel, Yunus A. 2003. Heat Transfer A Practicaol Approach, $2^{\text {nd }}$ edition. New York:McGraw-Hill Companies Inc.

Durst, Franz. 2008. Fluid Mechanics "An intoduction to the theory of fluid flows. Berlin Heidelberg : German. Springer - Verlag, Inc.

Eiamsa-ard, Smith. \& Promvonge, P. 2006. Heat transfer characteristics in a tube fitted with helical screw-tape with/without core-rod inserts. Bangkok: King Mongkuts Institute of Technology Ladkrabang. 
Eiamsa-ard, Smith. Pethkool, Somsak. Thianpong, Chinaruk. \& Promvonge, P. 2007

Turbulent Flow Heat Transfer and Pressure Loss in a Double Pipe Heat Exchanger with Louvered Strip Inserts. Bangkok: King Mongkuts Institute of Technology Ladkrabang.

Engineering data book III 5-1. Wolverine Tube Heat Transfer Data book. Wolverine Tube, Inc. URL : http://www.wlv.com/products/databook/ch2 2.pdf. 16 februari 2010.

Holman, J.P. 1997. Perpindahan Kalor, Edisi keenam. Terjemahan Ir. E. Jasfi M. Sc., Jakarta : Erlangga.

Incropera,F.P., De Witt, D.P. 1992. Fundamental of Heat Transfer, $6^{\text {nd }}$ edition. New York: John Willey and Sons.

Introduction to engineering heat transfer. URL : http://www.ocw.mit.edu/../10_part1_3.pdf. 16 Februari 2010.

Koestoer, Raldi A.dan Zulkifli. Perpindahan Kalor Konveksi 1998 Laboratorium Perpindahan Kalor Jurusan Mesin Fakultas Teknik Universitas Indonesia.

Lunsford, Kevin M. 1998. Increasing heat exchanger performance. Bryan : Texas US. Bryan Research \& Engineering, Inc.

Murugesan, P. 2009. Heat transfer and pressure drop characteristics of turbulent flow in a tube fitted with trapezoidal-cut twisted tape insert. Department of Mechanical Engineering, K. S. Rangasamy College of Technology. International Journal of Academic Research. URL : www.ijar.lit.az.

Nakayama, Y. 1998. Introduction to fluid mechanics "editor by R. F Boucher UMIST UK”. Butterworth-Heinemann, Linacre House, Jordan Hill, Oxford OX2 8DP 225 Wildwood Avenue, Woburn, MA 01801-2041A division of Reed Educational and Professional Publishing, Ltd.

Paul Singh, R. 2006. Design of a tubular heat exchanger. URL : http://web2.clarkson.edu/projects/subramanian/ch302/notes/designshelltube.p df.

Pethkool, Somsak. Eiamsa-ard, Smith. Ridluan, Artit. And Promvonge, P. 2006 Effect of Louvered Strips on Heat Transfer in a Concentric Pipe Heat Excahanger. Bangkok:King Mongkuts Institute of Technology Ladkrabang.

Saunders, E.A.D. 1986. Heat Exchangers Selection, Design and Construction. Darlington : Whessoe Heavy Engineering Ltd. 
Serth, Robert W. 2007. Process heat transfer "Principles and applications". ISBN: 0123735882. Elsevier Science \& Technology Books.

Shah, Ramesh K. \& Sekulic, Dušan P. 2003. Fundamentals of Heat Exchanger Design. Hoboken, New Jersey : John Wiley \& Sons, Inc.

Streeter, Victor L \& Wylie, E Benjamin. 1998. Fluid Mechanics . New York : McGraw-Hill, Inc.

White, Frank M. 2005. Fluid Mechanics $4^{\text {th }}$ edition. New York : WCB McGrawHill, Inc. 